\title{
6- $O$-DEMETHYL-5-DEOXYFUSARUBIN AND ITS ANHYDRO DERIVATIVE PRODUCED BY A MUTANT OF THE FUNGUS NECTRIA HAEMATOCOCCA BLOCKED IN FUSARUBIN BIOSYNTHESIS
}

\author{
Denise Parisot \\ Laboratoire de Cryptogamie, Bâtiment 400, Faculté des Sciences,
} 91405 Orsay Cedex, France

Michel Devys and Michel Barbier

Institut de Chimie des Substances Naturelles, CNRS, 91198 Gif sur Yvette Cedex, France

(Received for publication July 19, 1990)

\begin{abstract}
6-O-Demethyl-5-deoxyfusarubin and 6-O-demethyl-5-deoxyanhydrofusarubin have been isolated from the mutant redD169.yelY9 of the fungus Nectria haematococca blocked in fusarubin biosynthesis. These products were identified on the basis of physico-chemical data by comparison with known substances.
\end{abstract}

Cultures of the redD169 strain of the fungus Nectria haematococca (Berk. and Br.) Wr., the sexual form of Fusarium solani ${ }^{1)}$, contain a mixture of red substances composed primarily of the pyranonaphthoquinone fusarubin (3) and of related minor compounds ${ }^{2 \sim 7)}$. Fusarubin and several accompanying products have been reported to possess moderate antibacterial, antifungal, insecticidal and phytotoxic activities $^{8 \sim 12}$. The heptaketide origin of fusarubin was indicated by incorporation studies with ${ }^{13} \mathrm{C}$-acetate ${ }^{13)}$. We recently isolated fusarubinoic acid which appears to be the first cyclization product in the fusarubin series ${ }^{4}$. In the course of studying the biosynthetic pathway leading to fusarubin, we obtained several blocked mutants which were yellow-pigmented ${ }^{14}$ ). $N$. haematococca annA*58.yelJl, one of these mutant strains, has been reported to accumulate 4-deoxyfusarubin (4), 4-deoxyanhydrofusarubin (5) and 4-deoxyjavanicin (according to the present numbering system), together with minor, as yet unidentified compounds $^{15}$.<smiles>[R6]Oc1cc(O)c2c(c1)CC1=C(CC3=C(OC(C)(O)OC3=O)C1=O)C2=O</smiles>

1a $\quad \mathrm{R}=\mathrm{H}$

1b $\mathrm{R}=\mathrm{CH}_{3}$<smiles>[R20]Oc1cc([R20])c2c(c1)C(=O)C1=C(COC(C)=C1)C2=O</smiles>

2a $\quad \mathrm{R}_{1}=\mathrm{R}_{2}=\mathrm{H}$

2b $\quad \mathrm{R}_{1}=\mathrm{CH}_{3} \quad \mathrm{R}_{2}=\mathrm{H}$

2c $\mathrm{R}_{1}=\mathrm{R}_{2}=\mathrm{CH}_{3}$<smiles>COC1=CC(=O)c2c(O)c3c(c(O)c2C1=O)CC(C)(O)OC3</smiles>

3<smiles>COC1=CC(=O)c2c(cc3c(c2O)COC(C)(O)C3)C1=O</smiles>

4<smiles>COC1=CC(=O)c2c(cc3c(c2O)COC(C)=C3)C1=O</smiles>

5 
In this paper, we describe the isolation and identification of 6-O-demethyl-5-deoxyfusarubin (1a) and of 6-O-demethyl-5-deoxyanhydrofusarubin (2a), representative of a novel series of compounds produced by another blocked mutant: redD169.yelY9.

\section{Materials and Methods}

\section{Organism}

The yellow yelY9 mutant was derived from the homothallic S1 wild-type strain of $N$. haematoccocca ${ }^{14}$ ) after UV mutagenesis $\left(350 \mathrm{~J} / \mathrm{m}^{2}\right)$. A cross with the pigment overproducing red 169 mutant ${ }^{3)}$ yielded the deep-yellow redD169.yelY9 double-mutant used for this study.

\section{Culture Medium}

The production medium (GAMS) was composed of (g/liter): Glucose 22.5, L-asparagine $\cdot \mathrm{H}_{2} \mathrm{O} 0.95$, $\mathrm{KH}_{2} \mathrm{PO}_{4} 1, \mathrm{MgSO}_{4} \cdot 7 \mathrm{H}_{2} \mathrm{O} 0.5, \mathrm{KCl} 0.75, \mathrm{CaCl}_{2} \cdot 2 \mathrm{H}_{2} \mathrm{O} 0.15, \mathrm{FeSO}_{4} \cdot 7 \mathrm{H}_{2} \mathrm{O} 0.003, \mathrm{ZnSO}_{4} \cdot 7 \mathrm{H}_{2} \mathrm{O} 0.003$; $\mathrm{CuSO}_{4} \cdot 5 \mathrm{H}_{2} \mathrm{O} 0.00125, \mathrm{MnSO}_{4} \cdot \mathrm{H}_{2} \mathrm{O} 0.00035, \mathrm{Na}_{2} \mathrm{MoO}_{4} \cdot 2 \mathrm{H}_{2} \mathrm{O} 0.00025$ (pH 5.5). For large scale cultivation, 2 liters of GAMS were distributed into 80 Petri dishes $(25 \mathrm{ml}$ each).

\section{Cultivation}

Stock cultures were maintained on V8-vegetable juice-agar plates at $26^{\circ} \mathrm{C}$ and transferred monthly. Precultures were made by spreading microconidia removed from stock cultures onto plates of V8-vegetable juice-agar and incubated for 2 days at $26^{\circ} \mathrm{C}$. The conidia-bearing surface of a preculture was scraped into $10 \mathrm{ml}$ of sterile distilled water and $0.1 \mathrm{ml}$ of the conidial suspension was added to each $25 \mathrm{ml}$ of GAMS in Petri dishes. The cultures were incubated for 5 days at $26^{\circ} \mathrm{C}$.

\section{Isolation of Metabolites}

The mycelium was removed by filtration through filter paper on a Büchner funnel and washed with distilled water. The filtrate and washing were pooled and concentrated under reduced pressure to a volume of $500 \mathrm{ml}$. The concentrate ( $\mathrm{pH} 5.5$ ) was extracted four times with $500 \mathrm{ml}$ of ethyl acetate. The $\mathrm{pH}$ of the aqueous phase was then adjusted to 3 with acetic acid and the acidified solution was extracted twice with $500 \mathrm{ml}$ of EtOAc.

\section{Purification by Chromatography}

The extracts were pooled, concentrated under reduced pressure and fractionated by flash chromatography on silica gel. The eluting solvents consisted of pentane $(200 \mathrm{ml})$ followed by $9: 1$, pentane-EtOAc $(100 \mathrm{ml}) ; 3: 1$, pentane-EtOAc (2 liters); $1: 1$, pentane-EtOAc (1 liter); $1: 3$, pentane - EtOAc $(500 \mathrm{ml})$; EtOAc ( 1 liter); $49: 1$, EtOAc - acetic acid. The eluates were monitored by $\mathrm{SiO}_{2}$ TLC and appropriate fractions were then combined to give 7 fractions. Further purification of these fractions was accomplished by preparative TLC (elution with pentane-EtOAc (1:1)) or $\mathrm{SiO}_{2}$ column chromatography (elution with pentane-EtOAc mixtures).

\section{Analytical Instruments}

MP's were determined with a Kofler block under the microscope and are corrected. Electronic absorption spectra were recorded with a Varian Lambda-5 UV-visible spectrophotometer. IR spectra were obtained in pressed $\mathrm{KBr}$ discs using a Nicolet 205 FT-IR apparatus. EI mass spectra were measured on an AEI MS-50 spectrometer. ${ }^{1} \mathrm{H}$ and ${ }^{13} \mathrm{C}$ NMR spectra were recorded on Bruker 250 and $400 \mathrm{MHz} F$ spectrometers (DMSO- $d_{6}, \delta$ ppm from TMS as internal standard).

\section{Methylation of Compounds $1 \mathbf{a}$ and $\mathbf{2 a}$}

The compound 1a was dissolved into EtOAc $(5 \mathrm{mg} / 1 \mathrm{ml})$ and an excess of ethereal diazomethane $(4 \mathrm{ml})$ was added. The mixture was left at room temperature for about 1 hour. The reaction mixture was then evaporated to dryness under a nitrogen stream. $\mathrm{SiO}_{2} \mathrm{TLC}$ in $\mathrm{CH}_{2} \mathrm{Cl}_{2}-\mathrm{MeOH}(97: 3)$ showed a major yellow substance and at least four minor spots. These were separated by preparative $\mathrm{SiO}_{2} \mathrm{TLC}$ in 
$\mathrm{CH}_{2} \mathrm{Cl}_{2}-\mathrm{MeOH}(19: 1)$ to afford the methylated derivative $\mathbf{1 b}$. When substance $\mathbf{2 a}$ was treated with diazomethane as reported above, a dry residue was obtained which consisted (according to TLC) of at least 6 products. A purple $\mathbf{2 b}$ and a red $2 \mathbf{c}$ major compounds were isolated by preparative $\mathrm{SiO}_{2} \mathrm{TLC}$ using the mixture pentane $-\mathrm{CH}_{2} \mathrm{Cl}_{2}-\mathrm{MeOH}(4: 15: 1)$.

\section{Dehydration of Compound 1a}

The compound 1a was dissolved in acetic acid $(11 \mathrm{mg} / 1 \mathrm{ml})$ and heated for about 40 minutes at $55^{\circ} \mathrm{C}$. The color changed from yellow to purple. The reaction mixture was then diluted with $50 \mathrm{ml}$ EtOAc and evaporated to dryness under reduced pressure. $\mathrm{SiO}_{2} \mathrm{TLC}$ in $\mathrm{CH}_{2} \mathrm{Cl}_{2}-\mathrm{MeOH}(19: 1)$ showed a yellow minor spot corresponding to the starting product and a major purple compound with a $\mathrm{Rf}$ identical to that of substance 2a. Preparative TLC in the same solvent mixture afforded $8.5 \mathrm{mg}$ of pure product.

\section{Results and Discussion}

Characterization of the yelY9 and redD169.yelY9 Mutant Strains

Pure cultures of the yelY9 and redD169.yelY9 strains produced no pigments of the fusarubin series in any nutritional condition which was tested, but did produce yellow compounds. Red pigmented cultures containing fusarubin and related substances were obtained in co-synthesis experiments between redD169.yelY9 and the previously studied redD169.yelJl yellow double-mutant ${ }^{14}$. These results indicated that the yelY9 mutation was not an allele of yelJl although both prevented synthesis of fusarubin. As further confirmation of the non-identity of the yelY9 and yelJ1 mutant strains of $N$. haematococca, TLC analysis of EtOAc extracts from their culture filtrates showed two series of substances differing principally in their polarity. The two components 1a and 2 a were isolated from redD169.yelY9 culture filtrates and identified, respectively, as 6-O-demethyl-5-deoxyfusarubin and 6-O-demethyl-5-deoxyanhydrofusarubin on the basis of spectral and chemical analyses.

\section{Isolation and Structure Elucidation of Substance 2a}

Fraction I from flash chromatography contained a major purple compound $2 \mathbf{a}$. After purification by $\mathrm{SiO}_{2} \mathrm{TLC}$, substance $2 \mathrm{a}$ was crystallized from heptane $-\mathrm{CH}_{2} \mathrm{Cl}_{2}$ as dark-purple needles with $\mathrm{mp} 181 \sim 184^{\circ} \mathrm{C}$. The yield of crystalline product was of the order of $2 \mathrm{mg} /$ liter of culture filtrate. The spectral data are summarized in Table 1. The UV-visible spectrum of 2a exhibited maxima at 279, 355 and $509 \mathrm{~nm}$; the IR spectrum showed hydroxyl groups $\left(3440 \mathrm{~cm}^{-1}\right)$, a non-chelated $\left(1640 \mathrm{~cm}^{-1}\right)$ and a chelated $\left(1613 \mathrm{~cm}^{-1}\right)$ quinone carbonyl groups. The above data, together with a meta-coupling $(J=2.4 \mathrm{~Hz})$ of the aromatic protons at 6.50 and $6.93(5-\mathrm{H}$ and $7-\mathrm{H})$ and two phenolic protons at 11.72 and $12.88(6-\mathrm{OH}$ and $8-\mathrm{OH})$ in the NMR spectrum (Table 2) suggested the presence of a dihydroxynaphthoquinone moiety in $2 \mathbf{a}$. The ${ }^{1} \mathrm{H}$ NMR spectrum of $2 \mathrm{a}$ (Table 2) contained also three methyl protons at 2.03, two methylene protons at 5.07 and a vinylic proton at 5.85. The EI-MS showed the molecular ion at $m / z 258$ and fragments at 243 ,

Table 1. Physico-chemical characteristics of compounds $\mathbf{1 a}$ and $\mathbf{2 a}$.

\begin{tabular}{lll}
\hline & \multicolumn{1}{c}{ 1a } & \multicolumn{1}{c}{ 2a } \\
\hline MP $\left({ }^{\circ} \mathrm{C}\right)$ & $194 \sim 196$ & $181 \sim 184$ \\
$M S(m / z)(\%)$ & $276 \mathrm{M}^{+}(8), 258(\mathrm{M}-18)^{+}(100)$, & $258 \mathrm{M}^{+}(100), 243(\mathrm{M}-15)^{+}(16)$, \\
& $216(45), 188(31), 160(8), 43(62)$ & $228(15), 215(24)$ \\
UV $\lambda_{\text {max }}^{\mathrm{MeOH}} \mathrm{nm}(\varepsilon)$ & $215(4.20), 268(3.89), 288(\mathrm{sh} \mathrm{3.73),}$ & $279,355,509$ \\
& $442(3.34)$ & \\
$\mathrm{IR}(\mathrm{KBr}) \mathrm{cm}^{-1}$ & $3429(\mathrm{H}$-bonded $\mathrm{OH}), 1649(\mathrm{C}=\mathrm{O})$, & $3437(\mathrm{H}-$ bonded $\mathrm{OH}), 1644(\mathrm{C}=\mathrm{O})$, \\
& $1620(\mathrm{H}$-bonded $\mathrm{C}=\mathrm{O})$ & $1613(\mathrm{H}$-bonded $\mathrm{C}=\mathrm{O})$ \\
\hline
\end{tabular}


Table 2. ${ }^{1} \mathrm{H}$ NMR data for substances $\mathbf{1 a}, \mathbf{1 b}, \mathbf{2 a}, \mathbf{2 b}$ and $\mathbf{2 c}$.

\begin{tabular}{|c|c|c|c|c|c|}
\hline Protons & $1 \mathrm{a}$ & lb & $2 a$ & $2 b$ & $2 c$ \\
\hline $2 \cdot \mathrm{CH}_{3}$ & $1.43 \mathrm{~s}$ & $1.44 \mathrm{~s}$ & $2.03 \mathrm{~s}$ & $2.03 \mathrm{~s}$ & $2.02 \mathrm{~s}$ \\
\hline $2-\mathrm{OH}$ & $6.10 \mathrm{~s}$ & $6.11 \mathrm{~s}$ & & & \\
\hline \multirow[t]{4}{*}{$3-\mathrm{H}$} & $2.33]$ & 2.47 & $5.85 \mathrm{~s}$ & $5.90 \mathrm{~s}$ & $5.87 \mathrm{~s}$ \\
\hline & $2.43 \mathrm{dd}$ & $2.55 \mathrm{dd}$ & & & \\
\hline & $2.50\}^{\mathrm{dd}}$ & $2.65^{\mathrm{dod}}$ & & & \\
\hline & $2.60 \mathrm{~J}$ & $2.71\}$ & & & \\
\hline $5-H^{a}$ & $6.93 \mathrm{~d}$ & $7.04 \mathrm{~d}$ & $6.93 \mathrm{~d}$ & $7.0 \mathrm{~d}$ & $7.17 \mathrm{~d}$ \\
\hline 6-OH & $11.20 \mathrm{~s}$ & & $11.72 \mathrm{~s}$ & & \\
\hline $6-\mathrm{OCH}_{3}$ & & $3.91 \mathrm{~s}$ & & $3.93 \mathrm{~s}$ & $3.92 \mathrm{~s}$ \\
\hline $7-\mathrm{H}^{\mathrm{a}}$ & $6.50 \mathrm{~d}$ & $6.80 \mathrm{~d}$ & $6.50 \mathrm{~d}$ & $6.80 \mathrm{~d}$ & $7.0 \mathrm{~d}$ \\
\hline 8-OH & $12.0 \mathrm{~s}$ & $12.05 \mathrm{~s}$ & $12.88 \mathrm{~s}$ & $12.40 \mathrm{~s}$ & \\
\hline $8-\mathrm{OCH}_{3}$ & & & & & $3.98 \mathrm{~s}$ \\
\hline $10-H$ & $4.53 \mathrm{~s}$ & $4.51 \mathrm{~s}$ & $5.07 \mathrm{~s}$ & $5.10 \mathrm{~s}$ & $5.06 \mathrm{~s}$ \\
\hline
\end{tabular}

DMSO- $d_{6}, 250 \mathrm{MHz}, \delta$ ppm.

a $J=2.4 \mathrm{~Hz}$.

215,186 , thirty mass units lower than found for anhydrofusarubin ${ }^{13)}$. This fragmentation pattern suggested that substance 2a differed from anhydrofusarubin (4a) by the lack of an oxygen atom (16 mass units less) and a methyl group (14 mass units). Presumably, substance 2a was biogenetically related to anhydrofusarubin.

On methylation with an excess of diazomethane, 2a gave mainly the monomethyl derivative

Table 3. ${ }^{13} \mathrm{C}$ NMR data of substance 1a.

\begin{tabular}{cc|cc}
\hline C-atom & $\delta(\mathrm{ppm})$ & C-atom & $\delta(\mathrm{ppm})$ \\
\hline $\mathrm{C}-2$ & $93.1(\mathrm{Q})$ & $\mathrm{C}-7$ & 107.0 \\
$\mathrm{C}-3$ & 32.5 & $\mathrm{C}-8$ & $163.3(\mathrm{Q})$ \\
$\mathrm{C}-3 \mathrm{a}$ & $139.9(\mathrm{Q})$ & $\mathrm{C}-8 \mathrm{a}$ & $107.7(\mathrm{Q})$ \\
$\mathrm{C}-4$ & $182.4(\mathrm{Q})$ & $\mathrm{C}-9$ & $185.8(\mathrm{Q})$ \\
$\mathrm{C}-4 \mathrm{a}$ & $141.3(\mathrm{Q})$ & $\mathrm{C}-9 \mathrm{a}$ & 133.4 \\
$\mathrm{C}-5$ & 108.2 & $\mathrm{C}-10$ & 56.6 \\
$\mathrm{C}-6$ & $164.6(\mathrm{Q})$ & $2-\mathrm{CH}_{3}$ & 28.1 \\
\hline
\end{tabular}

DMSO- $d_{6}, \mathrm{Q}$ standing for quaternary C-atom. $\left(m / z 272, \mathbf{M}^{+}\right)$in addition to the dimethyl derivative which appeared to be identical with anhydroherbarin ${ }^{16)}$. The monomethyl derivative differed from the previously described 4-deoxyanhydrofusarubin (5) ${ }^{15)}$ by the following properties: Purple pigment (instead of red), $\mathrm{Rf}$ in $\mathrm{CH}_{2} \mathrm{Cl}_{2}(49: 1)$ 0.88 instead of 0.80 , meta-coupling $(J=2.4 \mathrm{~Hz})$ between the $5-\mathrm{H}$ and the $7-\mathrm{H}$ in NMR (no meta-coupling as might be expected in the case of substance $\mathbf{5}$ ).

\section{Isolation and Structure Elucidation of 1a}

Fraction II was composed of a main yellow substance 1a with pink and yellow products which occurred in trace amounts. The main product la was isolated by preparative TLC. Further purification was achieved by crystallization from heptane - ethyl acetate. About $10 \mathrm{mg}$ of yellow needles were obtained per liter of culture filtrate ( $\mathrm{mp} 194 \sim 196^{\circ} \mathrm{C}$ ). The molecular formula of $1 \mathrm{a}$ was determined to be $\mathrm{C}_{14} \mathrm{H}_{12} \mathrm{O}_{6}$ from the elemental analysis, the ${ }^{1} \mathrm{H}$ (12 protons) and ${ }^{13} \mathrm{C}$ NMR spectra.

\footnotetext{
Anal Calcd for $\mathrm{C}_{14} \mathrm{H}_{12} \mathrm{O}_{6}$ : C $60.86, \mathrm{H} 4.35$.
}

Found: $\quad \mathrm{C} 60.75, \mathrm{H} 4.46$.

The absorption maxima in the UV-VIS spectrum of 1a were found at $215,268,288$ and $442 \mathrm{~nm}$. In the ${ }^{1} \mathrm{H}$ NMR spectrum, the meta-coupling $(J=2.4 \mathrm{~Hz})$ of the aromatic proton signals was observed at 6.93 and 6.50 , the two phenolic proton signals were found at 11.20 and 12.0 (Table 2) while the ${ }^{13} \mathrm{C}$ signals at 185.8 , $182.4,164.6,163.3,141.3,139.9,133.4,108.2,107.7$ and 107.0 (Table 3) suggested the presence of a dihydronaphthoquinone moiety similar to that of $\mathbf{2 a}$. This structure was also consistent with the observation of the absorption of hydroxyl groups $\left(3430 \mathrm{~cm}^{-1}\right)$, a chelated $\left(1620 \mathrm{~cm}^{-1}\right)$ and a non-chelated $\left(1650 \mathrm{~cm}^{-1}\right)$ 
quinone carbonyls in the IR spectrum. With regard to the signals of $2-\mathrm{CH}_{3}$ at $1.43,3-\mathrm{CH}_{2}$ at $2.33 \sim 2.60$ (dd), $10-\mathrm{CH}_{2}$ at 4.53 and $2-\mathrm{OH}$ (tertiary) at 6.10 , the ${ }^{1} \mathrm{H}$ NMR spectrum of $1 \mathrm{a}$ also showed strong similarities to that of fusarubin (3). The mass spectrum was in accordance with the structure of an $O$-demethyldeoxyfusarubin. The loss of $\mathrm{H}_{2} \mathrm{O}$ from the molecular ion at $m / z 276$ resulted in the significant $(\mathrm{M}-18)^{+}$ion (base peak) at 258 . Further confirmation for the proposed structure 1a was obtained by dehydration in acetic acid, affording a product identical to $2 \mathbf{a}$. On methylation with an ethereal solution of diazomethane, 1a gave mainly the monomethyl derivative $\mathbf{1 b}, \mathrm{MS} m / z 290\left(\mathrm{M}^{+}\right)$. This derivative $\mathbf{1 b}$ differed from the previously reported 4-deoxyfusarubin ${ }^{15}$ (4) by a higher $\mathrm{Rf}$ and the observation in ${ }^{1} \mathrm{H}$ NMR of meta-coupling between the C-5 and C-7 aromatic protons, indicating that the methoxy group was bonded to the benzenoid ring as represented. Furthermore, the monomethyl derivative $\mathbf{1 b}$ could be dehydrated by treatment with acetic acid affording a purple compound identical to $\mathbf{2 b}$.

\section{Acknowledgments}

Thanks are due to Drs. B. C. DAS, C. Girard and J. P. Dupuis for MS determinations, to Mrs. C. PASQuiER and C. Fontaine for the ${ }^{1} \mathrm{H}$ and ${ }^{13} \mathrm{C}$ NMR spectra carried out at Gif sur Yvette, and to Mrs. L. Qualno for expert technical assistance.

\section{References}

1) Bоoth, C. (Ed.): The Genus Fusarium. pp. 44 48, Commonwealth Mycological Institute, Kew, England, 1971

2) Parisot, D.; M. Devys \& M. Barbier: Pigments from Nectria haematococca: Anhydrofusarubin lactone and nectriafurone. Phytochemistry 22: $1301 \sim 1303,1983$

3) Parisot, D.; M. Devys \& M. BARBIER: A major naphthoquinone, 13-hydroxynorjavanicin isolated from an overproducing strain of Nectria haematococca (Berk, and Br.) Wr. Microbios Lett. 36: 129 132, 1987

4) Parisor, D; M. Devys \& M. Barbier: Fusarubinoic acid, a new naphthoquinone from the fungus Nectria haematococca. Phytochemistry 27: 3002 3004, 1988

5) Barbier, M.; M. Devys \& D. Parisot: A new dihydrofusarubin-O-ethyl ether produced by the fungus Nectria haematococca (Berk. and Br.) Wr. Can. J. Chem. 66: 2803 2804, 1988

6) Parisot, D.; M. Devys \& M. Barbier: Anhydrofusarubin lactol from Nectria haematococca. Phytochemistry 28 : $3240 \sim 3241,1989$

7) Parisot, D.; M. DevYs \& M. Barbier: Conversion of anhydrofusarubin lactol into the antibiotic bostrycoidin. J. Antibiotics 42: $1189 \sim 1190,1989$

8) KERN, H.: Les naphthazarines des Fusarium. Ann. Phytopathol. 10: 327 345, 1978

9) Ammar, M. S.; N. N. Gerber \& L. E. MCDaniel; New antibiotic pigments related to fusarubin from Fusarium solani (MART.) SACC. I. Fermentation, isolation, and antimicrobial activities. J. Antibiotics 32: 679 684, 1979

10) BAKer, R. A.; J. H. TAtuM \& S. NemEC, Jr.: Toxin production by Fusarium solani from fibrous roots of blight-diseased Citrus. Phytopathol. 71: 951 954, 1981

11) Kimura, Y.; A. Shimada, H. Nakajima \& T. Hamasaki: Structures of naphthoquinones produced by the fungus, Fusarium sp., and their biological activity toward pollen germination. Agric. Biol. Chem. 52: 1253 1259, 1988

12) Claydon, N.; J. F. Grove \& M. Pople: Insecticidal secondary metabolic products from the entomogenous fungus Fusarium solani. J. Invertebr. Pathol. 30: 216 223, 1977

13) Kurobane, I.; L. C. Vining, A. G. McInnes \& J. A. Walter: Use of ${ }^{13} \mathrm{C}$ in biosynthetic studies. The labelling pattern in dihydrofusarubin enriched from ${ }^{13} \mathrm{C}$ and ${ }^{13} \mathrm{C},{ }^{3} \mathrm{H}$-acetate in cultures of Fusarium solani. Can. J. Chem. 58: $1380 \sim 1385,1980$

14) Parisot, D.; M. Maugin \& C. Gerlinger: Genes controlling pigmentation in Nectria haematococca. J. Gen. Microbiol. 130: 1543 1555, 1984

15) Parisot, D.; M. Devys \& M. Barbier: Structure and biosynthesis of 5-deoxyfusarubin and anhydro-5deoxyfusarubin, naphthoquinone pigments from Nectria haematococca. Phytochemistry 24: 1977 1979, 1985

16) Nagarajan, R.; N. Narasimhachari, M. V. Kadkol \& K. S. Gopalkrishnan: Structure of herbarin. J. Antibiotics 24: $249 \sim 252,1971$ 